\title{
Conceptualizations of clinical leadership: a review of the literature
}

\author{
This article was published in the following Dove Press journal: \\ Journal of Healthcare Leadership \\ 27 October 2017 \\ Number of times this article has been viewed
}

\section{Solange Mianda \\ Anna S Voce}

Department of Public Health Medicine, School of Nursing and Public Health, College of Health Sciences, University of KwaZuluNatal, Durban, South Africa
Correspondence: Solange Mianda Department of Public Health Medicine, School of Nursing and Public Health, College of Health Sciences, University of KwaZulu-Natal, Room 236, Second Floor George Campbell Building, Durban, South Africa

Tel +27842794310

Email solange.zoe60@gmail.com
Introduction: Poor patient outcomes in South African maternal health settings have been associated with inadequately performing health care providers and poor clinical leadership at the point of care. While skill deficiencies among health care providers have been largely addressed, the provision of clinical leadership has been neglected. In order to develop and implement initiatives to ensure clinical leadership among frontline health care providers, a need was identified to understand the ways in which clinical leadership is conceptualized in the literature.

Design: Using the systematic quantitative literature review, papers published between 2004 and 2016 were obtained from search engines (Google Scholar and EBSCOhost). Electronic databases (CINHAL, PubMed, Medline, Academic Search Complete, Health Source: Consumer, Health Source: Nursing/Academic, ScienceDirect and Ovid ${ }^{\circledR}$ ) and electronic journals (Contemporary Nurse, Journal of Research in Nursing, Australian Journal of Nursing and Midwifery, International Journal of Clinical Leadership) were also searched.

Results: Using preselected inclusion criteria, 7256 citations were identified. After screening 230 potentially relevant full-text papers for eligibility, 222 papers were excluded because they explored health care leadership or clinical leadership among health care providers other than frontline health care providers. Eight papers met the inclusion criteria for the review. Most studies were conducted in high-income settings. Conceptualizations of clinical leadership share similarities with the conceptualizations of service leadership but differ in focus, with the intent of improving direct patient care. Clinical leadership can be a shared responsibility, performed by every competent frontline health care provider, regardless of the position in the health care system. Conclusion: Conceptualizations of clinical leadership among frontline health care providers arise mainly from high-income settings. Understanding the influence of context on conceptualizations of clinical leadership in middle- and low-income settings may be required.

Keywords: clinical leadership, conceptualizations, frontline health care providers

\section{Introduction}

Clinical leadership plays a key role in ensuring both quality patient care and creating a healthy and safe clinical work environment. ${ }^{1-3}$ Poor patient care and adverse events have been reported in health facilities around the world, prompting health systems to call for strong clinical leadership. ${ }^{1-3}$

In South Africa, in maternal health settings, poor care has been associated with inadequate competencies among health care providers and poor clinical leadership, ${ }^{4,5}$ resulting in recommendations emphasizing the need to improve clinical skills and to improve clinical mentoring and clinical leadership. ${ }^{2,4,5}$ While programs to develop clinical skills, particularly lifesaving skills, have been rolled out actively, ${ }^{6,7}$ less attention has been paid to the provision of clinical leadership. 
Initiatives to promote and develop clinical leadership among frontline health care providers have been implemented in the UK, the USA, Canada and Australia. However, in Africa generally and in South Africa specifically, there has been slow progress in promoting and developing clinical leadership among frontline health care providers, ${ }^{8}$ with the concepts of clinical leadership and clinical leadership development still underresearched. ${ }^{8}$ Furthermore, the literature on leadership in the health sector focuses mostly on health service leadership rather than on clinical leadership of frontline health care providers. ${ }^{9}$

Frontline health care providers, for example, nurses, midwives, allied health care providers and doctors providing direct patient care, are well positioned for providing, and benefiting from, the clinical leadership required to ensure both quality patient care and a healthy and safe clinical work environment. ${ }^{1,10-12}$ However, in many cases, frontline health care providers are neither clear about what is clinical leadership nor are well prepared to provide it. ${ }^{2,13,14}$ Moreover, frontline health care providers do not have clear career pathways to encourage them to engage in clinical leadership roles. ${ }^{9}$

Toward describing what is clinical leadership among frontline health care providers, a literature review was conducted as part of a doctoral research project. The overall aim of the doctoral project was to develop a model of clinical leadership among frontline health care providers in labor wards of district hospitals in KwaZulu-Natal, South Africa.

\section{Aim}

The aim of the literature review was to establish from published literature how clinical leadership is conceptualized, from the perspective of frontline health care providers.

\section{Design}

The systematic quantitative literature review method ${ }^{15}$ was followed to search and identify relevant literature and to extract conceptualizations of clinical leadership among frontline health care providers. Published literature was reviewed and guided by the question: "How is clinical leadership conceptualized among frontline health care providers"?

\section{Search method}

The search started within large search engines (Google Scholar and EBSCOhost). The search extended to electronic databases (CINHAL, PubMed, Medline, Academic Search Complete, Health Source: Consumer, Health Source: Nursing/Academic, ScienceDirect and Ovid $\left.{ }^{\circledR}\right)$. Lastly, electronic journals (Contemporary Nurse, Journal of Research in
Nursing, Australian Journal of Nursing and Midwifery, International Journal of Clinical Leadership) were searched. The search was limited to articles published between 2004 and 2016, to ensure the most recent published literature would be obtained through the review. The search terms included "clinical leadership" in combination with: "conceptualization", "characteristics", "definition", "medical”, "perceptions", "perspectives" and "roles"; and "frontline leadership" in combination with: "nursing", "perceptions", "perspectives", "roles", "characteristics", "conceptualization" and "definition". The reference sections of accessed articles were also consulted to ensure the review was comprehensive.

Research papers were considered for inclusion in the review if they met the following criteria: 1) original research paper published in a peer-reviewed journal; 2) gray literature; 3) exploring definitions/conceptualizations/perceptions of clinical leadership; 4) from the perspectives of frontline health care providers; and 5) published in the English language. Studies that did not explore clinical leadership among frontline health care providers, studies that explored health care leadership, literature reviews and systematic reviews were excluded.

\section{Assessing publications}

The literature search resulted in 7256 citations. Figure 1 presents the study flow mapping out the number of records identified, included and excluded and the reasons for their exclusion. After screening 230 potentially relevant full-text papers for eligibility, 183 papers were excluded because they explored health care leadership and 39 papers were excluded for not exploring clinical leadership among frontline health care providers or being literature reviews. Eight papers met the inclusion criteria and were analyzed for the review.

The quality of studies reviewed was appraised using the most appropriate tool. The "strengthening the reporting of observational studies in epidemiology" (STROBE), ${ }^{16}$ the "consolidated criteria for reporting qualitative research" (COREQ) $)^{17}$ and the "mixed methods appraisal tool" $(\text { MMAT })^{18}$ were used for the appraisal. Against the STROBE criteria, the articles reporting the results of the quantitative studies did not provide clear descriptions of study designs. However, they included sound descriptions of variables, data collection methods and data analysis. Against the COREQ criteria, the qualitative studies contained several shortcomings, particularly related to the implementation of critical reflexivity ${ }^{19,20}$ and the relationship between researchers and participants. Furthermore, poor alignment was observed between the reported methodological orientation underpinning the studies and the data collection and analysis 


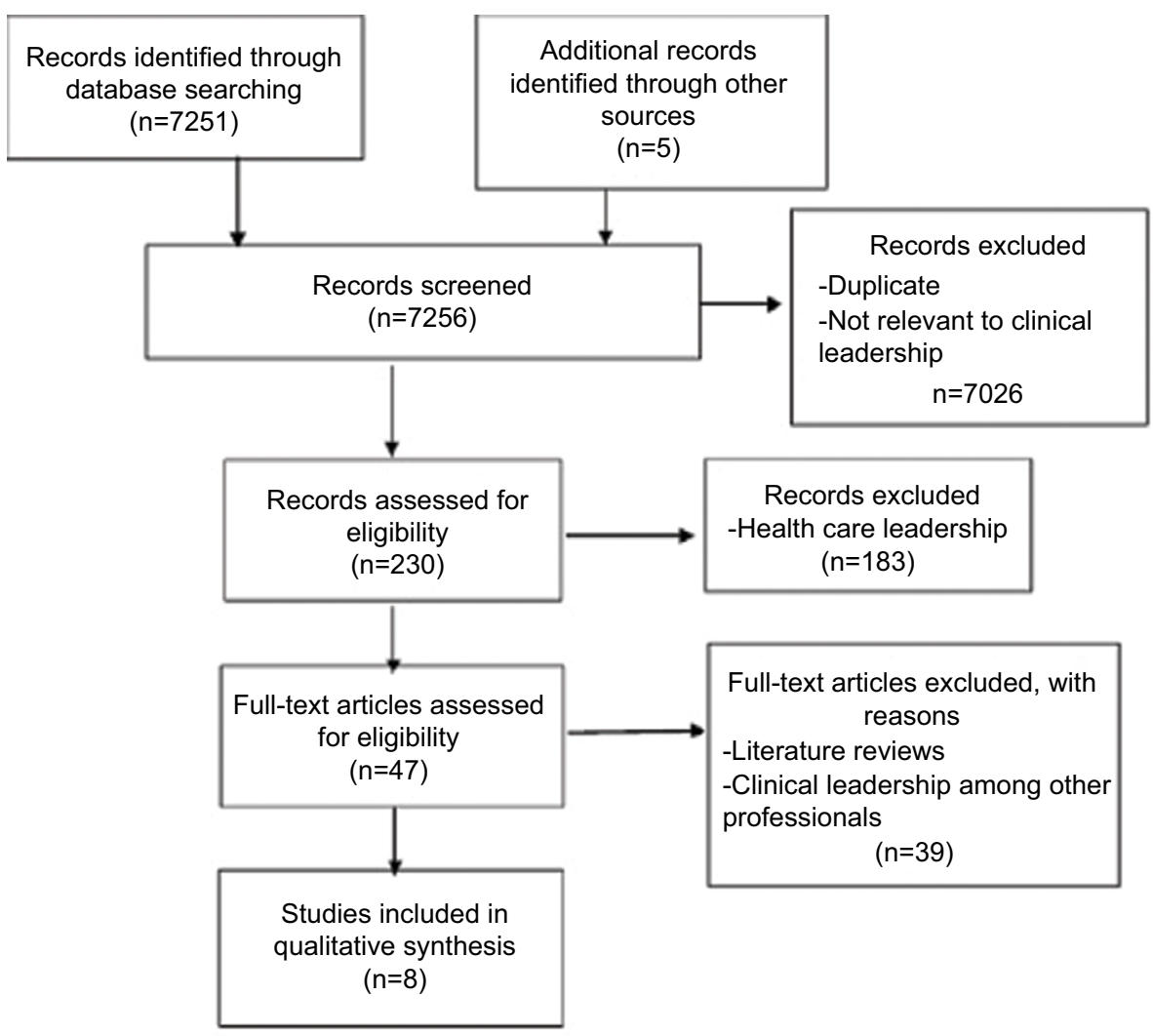

Figure I Study flow mapping out the number of records identified, included and excluded and the reasons for their exclusion.

methods. Against the MMAT criteria, although the rationale for integrating quantitative and qualitative methods was explained, there was neither clear indication of the process implemented for the integration of data nor clear indication of the limitations associated with the integration. Overall, studies used appropriate methodological approaches. Two studies, one qualitative and the other quantitative, utilized research designs with sufficient strength to produce transferable and generalizable findings..$^{21,22}$ The deficiencies identified in different studies did not detract from the purpose of this literature review.

\section{Constructing the database}

From each paper exploring conceptualizations of clinical leadership, the following information was recorded in a database: setting where the study was conducted; study aim, study design, study population and sample size; the clinical field in which the studies were conducted and conceptualizations of clinical leadership.

\section{Recording data in the database}

Papers were recorded in the database to check whether the categories created assisted to capture relevant data. No corrections were needed with the categories identified. The method section for the literature review was drafted. Finally, articles included were thematically analyzed to establish conceptualizations of clinical leadership among frontline health care providers.

\section{Results}

A total of eight papers published between 2004 and 2016 were included in this review. Table 1 presents the characteristics of identified studies.

\section{Study settings}

Three papers report on studies conducted in Australia, ${ }^{19,23,24}$ three in the UK,,$^{20,21,25}$ one in Ireland ${ }^{14}$ and one study conducted in New Zealand. ${ }^{22}$

\section{Aims of the studies}

All eight studies were designed to identify, explore, investigate, describe or capture the views of frontline health care providers on the concept of clinical leadership.

\section{Study design}

The papers included in the review reported on the implementation of a diversity of study designs: qualitative, quantitative and mixed method designs were used. 
Table I Characteristics of identified studies

\begin{tabular}{|c|c|c|c|c|c|}
\hline $\begin{array}{l}\text { Study } \\
\text { setting } \\
\text { and author } \\
\text { (year) }\end{array}$ & Study aim & Study design & $\begin{array}{l}\text { Study } \\
\text { population } \\
\text { and sample } \\
\text { size }\end{array}$ & $\begin{array}{l}\text { Clinical } \\
\text { field }\end{array}$ & $\begin{array}{l}\text { Key findings - clinical leadership } \\
\text { conceptualized as }\end{array}$ \\
\hline $\begin{array}{l}\text { Australia; } \\
\text { Stanley et al } \\
(20 / 3)^{23}\end{array}$ & $\begin{array}{l}\text { Identify } \\
\text { how clinical } \\
\text { leadership } \\
\text { is perceived } \\
\text { based on the } \\
\text { experiences } \\
\text { of ambulance } \\
\text { service staff }\end{array}$ & $\begin{array}{l}\text { Study design: sequential mixed method } \\
\text { using: literature review and expert } \\
\text { review to inform questionnaire design, } \\
\text { quantitative descriptive survey and } \\
\text { qualitative descriptive survey } \\
\text { Data collection: document reviews, } \\
\text { self-administered questionnaires and } \\
\text { individual in-depth interviews } \\
\text { Data analysis: thematic analysis to } \\
\text { develop questionnaire, descriptive } \\
\text { statistics for characteristics of clinical } \\
\text { leaders and thematic analysis for } \\
\text { conceptualizations of clinical leadership }\end{array}$ & $\begin{array}{l}\text { Ambulance } \\
\text { service staff } \\
-250\end{array}$ & $\begin{array}{l}\text { Ambulance } \\
\text { services }\end{array}$ & $\begin{array}{l}\text { - the qualities and competence of } \\
\text { leaders (caring, moral values, skill and } \\
\text { experience ability to promote change, } \\
\text { ability to impact on standards of care) } \\
\text { - having the resources necessary to } \\
\text { perform tasks effectively }\end{array}$ \\
\hline $\begin{array}{l}\text { Australia; } \\
\text { Stanley et al } \\
(2017)^{24}\end{array}$ & $\begin{array}{l}\text { Identify how } \\
\text { the concept } \\
\text { of clinical } \\
\text { leadership is } \\
\text { perceived by } \\
\text { allied health } \\
\text { professionals }\end{array}$ & $\begin{array}{l}\text { Study design: quantitative descriptive } \\
\text { survey } \\
\text { Data collection method: self- } \\
\text { administered, closed questions with } \\
\text { open options } \\
\text { Data analysis: descriptive statistics and } \\
\text { content analysis }\end{array}$ & $\begin{array}{l}\text { Allied health } \\
\text { professionals } \\
-307\end{array}$ & $\begin{array}{l}\text { Allied health } \\
\text { professions }\end{array}$ & $\begin{array}{l}\text { - the qualities and competence of } \\
\text { leaders (communication, clinical } \\
\text { competence, approachability, setting } \\
\text { direction, role model) } \\
\text { - a responsibility/role for everyone } \\
\text { and not located at specific levels } \\
\text { within the health system }\end{array}$ \\
\hline $\begin{array}{l}\text { Australia; } \\
\text { Ennis et al } \\
(2015)^{19}\end{array}$ & $\begin{array}{l}\text { Explore the } \\
\text { perceptions of } \\
\text { nurses of what } \\
\text { constitutes } \\
\text { effective } \\
\text { clinical } \\
\text { leadership }\end{array}$ & $\begin{array}{l}\text { Study design: grounded theory } \\
\text { Data collection method: semi- } \\
\text { structured and individual interviews } \\
\text { Data analysis: constant comparative } \\
\text { analysis }\end{array}$ & Nurses - 12 & $\begin{array}{l}\text { Mental } \\
\text { health }\end{array}$ & $\begin{array}{l}\text { - the qualities and competence } \\
\text { of leaders (ability to remain calm } \\
\text { and confident in time of crisis and } \\
\text { uncertainty, manage unpredictable } \\
\text { situations) }\end{array}$ \\
\hline $\begin{array}{l}\text { UK; Burns } \\
(2009)^{21}\end{array}$ & $\begin{array}{l}\text { Explore the } \\
\text { concept } \\
\text { of clinical } \\
\text { leadership }\end{array}$ & $\begin{array}{l}\text { Study design: descriptive } \\
\text { phenomenology } \\
\text { Data collection method: in-depth } \\
\text { individual interviews } \\
\text { Data analysis: descriptive } \\
\text { phenomenology }\end{array}$ & $\begin{array}{l}\text { General } \\
\text { practice } \\
\text { nurses - } 12\end{array}$ & Nursing & $\begin{array}{l}\text { - the qualities and competence of } \\
\text { leaders (being there; available to } \\
\text { support, advise, encourage and guide } \\
\text { as necessary; understanding of the } \\
\text { role of clinical leadership to provide } \\
\text { support as required) }\end{array}$ \\
\hline $\begin{array}{l}\text { UK; British } \\
\text { Medical } \\
\text { Association } \\
(2012)^{25}\end{array}$ & $\begin{array}{l}\text { Explore } \\
\text { perspectives } \\
\text { of medical } \\
\text { doctors } \\
\text { on clinical } \\
\text { leadership }\end{array}$ & $\begin{array}{l}\text { Study design: not specified } \\
\text { Data collection method: focus group } \\
\text { discussions and semi-structured } \\
\text { questionnaires } \\
\text { Data analysis: not specified (probably } \\
\text { thematic analysis) }\end{array}$ & $\begin{array}{l}\text { Doctors (GPs, } \\
\text { consultants, } \\
\text { staff grade, } \\
\text { specialty } \\
\text { doctors, } \\
\text { associate } \\
\text { specialists) } \\
\text { - } 70\end{array}$ & & $\begin{array}{l}\text { - the qualities and competence of } \\
\text { leaders (role modeling, provide vision, } \\
\text { able to gain support and influence } \\
\text { others, demonstrate expertise) } \\
\text { - being clinically engaged } \\
\text { - distinct from (health service) } \\
\text { management }\end{array}$ \\
\hline $\begin{array}{l}\text { UK; Mendis } \\
\text { and Paton } \\
(2014)^{20}\end{array}$ & $\begin{array}{l}\text { Explore } \\
\text { opinions } \\
\text { on clinical } \\
\text { leadership }\end{array}$ & $\begin{array}{l}\text { Study design: sequential mixed } \\
\text { methods; literature review to inform } \\
\text { questionnaire design, quantitative } \\
\text { descriptive survey and qualitative } \\
\text { descriptive survey } \\
\text { Data collection: self-administered } \\
\text { questionnaires with multiple answer } \\
\text { options and individual semi-structured } \\
\text { interviews with open-ended options } \\
\text { Data analysis: descriptive statistics and } \\
\text { thematic analysis }\end{array}$ & $\begin{array}{l}\text { Trainee } \\
\text { registrars - } \\
247\end{array}$ & Medicine & $\begin{array}{l}\text { - the qualities and competence } \\
\text { of leaders (reflective practice, } \\
\text { moral values, do no harm, good } \\
\text { communication skills, role model, } \\
\text { competence, clinical decision-making, } \\
\text { acting in the patient best interest) } \\
\text { - important in promoting } \\
\text { professionalism and teamwork } \\
\text { - delivering change in patient care }\end{array}$ \\
\hline
\end{tabular}


Table I (Continued)

\begin{tabular}{|c|c|c|c|c|c|}
\hline $\begin{array}{l}\text { Study } \\
\text { setting } \\
\text { and author } \\
\text { (year) }\end{array}$ & Study aim & Study design & $\begin{array}{l}\text { Study } \\
\text { population } \\
\text { and sample } \\
\text { size }\end{array}$ & $\begin{array}{l}\text { Clinical } \\
\text { field }\end{array}$ & $\begin{array}{l}\text { Key findings - clinical leadership } \\
\text { conceptualized as }\end{array}$ \\
\hline $\begin{array}{l}\text { Ireland; } \\
\text { McNamara } \\
\text { et al }(20 \mathrm{I} I)^{14}\end{array}$ & $\begin{array}{l}\text { Describe } \\
\text { views of } \\
\text { clinical } \\
\text { leadership }\end{array}$ & $\begin{array}{l}\text { Study design: not specified } \\
\text { Data collection method: focus group } \\
\text { discussions using topic guide } \\
\text { Data analysis: thematic analysis }\end{array}$ & Nurses - 144 & $\begin{array}{l}\text { Nursing and } \\
\text { midwifery }\end{array}$ & $\begin{array}{l}\text { - the qualities and competence of } \\
\text { leaders (influencing and motivating } \\
\text { others to deliver effective patient } \\
\text { care, requiring practical expertise) } \\
\text { - representing the nursing } \\
\text { contribution to care } \\
\text { - effective teamwork }\end{array}$ \\
\hline $\begin{array}{l}\text { New Zealand; } \\
\text { Trimmer } \\
(2007)^{22}\end{array}$ & $\begin{array}{l}\text { Explore the } \\
\text { perception } \\
\text { of clinical } \\
\text { leadership }\end{array}$ & $\begin{array}{l}\text { Study design: quantitative, descriptive } \\
\text { and comparative } \\
\text { Data collection: self-administered } \\
\text { closed questions with open options } \\
\text { distributed via mail } \\
\text { Data analysis: descriptive, comparative } \\
\text { statistics and thematic analysis of open } \\
\text { questionnaire }\end{array}$ & $\begin{array}{l}\text { Registered } \\
\text { nurses - 2I }\end{array}$ & $\begin{array}{l}\text { Mental } \\
\text { health }\end{array}$ & $\begin{array}{l}\text { - the qualities and competence of } \\
\text { leaders (role model, mentor, assess } \\
\text { performance, communicate) } \\
\text { - related to staff retention } \\
\text { - improving patient outcomes } \\
\text { - related to organizational support } \\
\text { - continued medical education }\end{array}$ \\
\hline
\end{tabular}

Abbreviation: GP, general practitioner.

Grounded theory and phenomenology were used inductively to generate conceptualizations of clinical leadership from the experiences of frontline health care providers. Constant comparative analysis and thematic analysis contributed to identifying key domains of clinical leadership from the perspectives of frontline health care providers.

Deductive quantitative designs were used to test the level of agreement with variables contained in existing frameworks describing clinical leadership. Based on the scoring of descriptive statements, conceptualizations of clinical leadership were advanced.

Sequential mixed methods design used literature reviews, expert reviews and in-depth interviews to inform questionnaire design to advance descriptions of clinical leadership, with which respondents could indicate the level of agreement.

\section{Study population and sampling strategies}

Studies comprised frontline health care providers (nurses, midwives, ambulance personnel, allied health professionals and doctors from different specialties).

Purposive sampling was used in the qualitative studies to select participants. Homogeneous sampling was used to capture the perspectives of clinical leadership from a particular perspective, for example, nurses, midwives, allied health professionals or ambulance personnel. Heterogeneous sampling was used to elicit multiple perspectives on clinical leadership, for example, doctors from different specialties. Online surveys, training programs, student databases and health service provision sites were used to recruit participants in the quantitative studies. The response rates of survey questionnaires ranged between $6.1 \%$ and $56.0 \%$. The sample sizes enrolled in the identified studies ranged from small numbers $(n=12)$ in the qualitative studies to relatively large numbers in the survey-based designs $(\mathrm{n}=307)$.

\section{Clinical field in which the studies were conducted}

Conceptualizations of clinical leadership were explored from the perspective of frontline health care providers in mental health, medical practice, nursing and midwifery, ambulance services and residential facilities. Allied health professionals' perspectives on clinical leadership were also explored.

\section{Conceptualizations of clinical leadership}

Conceptualizations of clinical leadership as gleaned from the studies included in the review can be grouped into six distinctive broad themes:

1. Clinical leadership conceptualized as having a focus on patient care: clinical leadership was conceptualized as having a focus on direct patient care. . $^{1420,22}$

2. Clinical leadership conceptualized as purpose: clinical leadership was conceptualized as having the purpose of delivering change in the quality of direct patient care and, furthermore, to motivate members of the team to provide effective health care that is safe and satisfying to patients. Clinical leadership was also perceived as having 
the purpose of promoting staff retention and providing organizational support, in the effort to improve patient outcomes. ${ }^{14,20,23}$

3. Clinical leadership conceptualized as the qualities of clinical leaders: clinical leadership was conceptualized as the qualities and competencies of clinical leaders. Qualities attributed to effective clinical leaders include approachability, role modeling, visibility and availability to support, advise and guide, capacity to remain calm and confident in crisis, ability to gain support and influence others, ability to promote change, ability to communicate effectively and impact on standards of care. ${ }^{14,19-23,25}$

4. Clinical leadership conceptualized as the competencies of clinical leaders: clinical leaders' competencies included demonstrating clinical expertise; being clinically focused, remaining clinically engaged, understanding clinical leadership roles and clinical decision making. ${ }^{14,19-23,25}$

5. Clinical leadership conceptualized as roles: clinical leadership was conceptualized as a role to be fulfilled by every frontline health care provider, regardless of the position in the health system. Clinical leadership roles identified included setting direction, providing the vision and promoting professionalism, teamwork, interprofessional collaborations, good practice and continued medical education. Clinical leadership was also perceived as representing the nursing contribution to patient care and having the resources to perform tasks effectively. ${ }^{14,22,23}$

6. Clinical leadership conceptualized as distinct from health service management: clinical leadership was not linked to a position held within the management structure and hierarchy of the organization. ${ }^{19,20,24,25}$

\section{Discussion}

This review was conducted to explore conceptualizations of clinical leadership in the literature, from the perspectives of frontline health care providers. Eight papers met the inclusion criteria. The papers were reviewed for quality and content, and conceptualizations of clinical leadership were summarized and synthesized.

All eight papers included in the review reflect studies conducted in high-income settings. Although health systems around the world share basic similar structures, the context in which clinical leadership is exercised might differ between high-income and low- and middle-income settings. Low- and middle-income settings generally suffer from underresourced and poorly managed health systems, ${ }^{8}$ which might challenge clinical leadership and the ways in which it is conceptualized and experienced by health care providers.
Thus, transferability of findings from this literature review to clinical leadership among frontline health care providers in South African labor wards might be compromised. Original research focusing on conceptualizations of clinical leadership in low-and middle-income settings, including South Africa, is recommended for understanding contextual influences on conceptualizations of clinical leadership among frontline health care providers.

Conceptualizations of clinical leadership uncovered in this review were thematically depicted as purpose, as qualities of leaders, as competence of leaders, as a set of roles to be performed and as a position of authority. The thematic depictions of clinical leadership may not be conceptually distinct from conceptualizations of health services leadership. ${ }^{26}$ Clinical leadership and health service leadership may indeed be similarly conceptualized and share characteristics. ${ }^{3,26}$ However, a different focus may be evident, with clinical leadership focusing on direct patient care ${ }^{14,21,22}$ and health service leadership focusing on providing a supportive context (policy, strategy and resource allocation), within which effective clinical leadership and optimal patient care may be exercised. ${ }^{3,26}$

Clinical leadership is distinct from health service management. ${ }^{19,20,24,25}$ In clinical settings, clinical decisions are made by frontline health care providers within clinical teams. ${ }^{2,27,28}$ Frontline health care providers exercise their leadership roles in health service management through expert power, by virtue of their training and specialist knowledge, rather than through a position in the management hierarchy. ${ }^{27,29}$

Clinical leadership was conceptualized as a role to be performed by every frontline health care provider in direct contact with patients, regardless of the position held in the organizational hierarchy. ${ }^{14,21,22,27}$ Shared clinical leadership models depart from traditional leadership models in that leadership is distributed among individuals instead of being embodied in one individual. ${ }^{28,30}$ Shared clinical leadership promotes teamwork, where each team member's skills and experiences are valued and used to attain optimal patient outcomes. ${ }^{28,30}$ Shared clinical leadership relies on human relations, influence and democracy, within flatter organizational structures. ${ }^{27,28}$ The challenges with shared clinical leadership, however, might be how to adopt models of shared clinical leadership in predominantly hierarchical organizational structures. ${ }^{28,31}$ In emergency situations when rapid decisions are required, the democratic nature of decision making in shared leadership might not allow sufficient consultation with everyone involved. ${ }^{28,31}$ Shared clinical leadership may be thwarted in clinical settings where professional power 
differentials exist, for example, in doctor-led services, where nurses and midwives may be reticent to make clinical decisions they indeed are empowered to make. ${ }^{32,33}$

The purpose of clinical leadership appears to be influenced by a service orientation, ${ }^{14,21-23,34}$ primarily service to patients and secondarily to staff, but for the sake of optimal patient care. ${ }^{11}$

Frontline health care providers conceptualized clinical leadership as a set of roles, highlighting the roles of the leader as visionary, as a role model and as an expert, coach and mentor that contribute to building excellence and interpersonal trust and teamwork. ${ }^{14,21-23}$

Conceptualizations of clinical leadership, which foregrounded the qualities and competencies of clinical leaders, may be influenced by trait and behavioral leadership theories. ${ }^{14,19,20,23,24,26}$ However, a particular emphasis seems to have been placed on the actual clinical expertise of the clinical leader. ${ }^{22,25}$ This suggests that fundamental to the provision of clinical leadership is clinical competence. Clinical competence is required to build the clinical skills and expertise of the individual and team and to lift standards of patient care. ${ }^{23}$ Approaches to building clinical competence can incorporate principles of shared leadership in an organizational culture of cooperation toward the attainment of optimal patient care. ${ }^{28,35}$

Conceptualizations of clinical leadership from the perspective of frontline health care providers were extracted from the literature, identifying key features of clinical leadership. However, what does not transpire from the literature is how the conceptual characteristics of clinical leadership are implemented in the clinical setting. Hence, one potential research agenda is to conduct a primary study to establish how different conceptual characteristics of clinical leadership are connected to optimal patient care. Furthermore, the body of published works on clinical leadership from the perspective of frontline health care providers is limited and therefore does not permit comparisons of conceptualizations among different clinical professions. A primary study to explore profession-specific conceptualizations may well be indicated.

\section{Strengths of the study}

This review highlights the diversity, extent and gaps of the research on the conceptualizations of clinical leadership among frontline health care providers. Further, the review has identified key directions for further research on conceptualizations of clinical leadership.

\section{Limitations of the study}

Although rigorous steps were followed in this review, we are also aware of some limitations.

- First, studies may have been omitted from the review if they were not published in the databases searched or if they were published in languages other than English.

- Second, the decision to limit the search to articles that reported conceptualizations of clinical leadership among "frontline health care providers" reduced the range of articles included in the review.

\section{Conclusion}

Frontline health care providers through this review conceptualized clinical leadership as purpose, qualities and competence of leaders, as a set of roles to be performed and as a position held in the organizational hierarchy. Frontline health care providers conceptualized clinical leadership as being distinct from health service leadership, with a direct patient care focus requiring highly clinically competent frontline health care providers to produce optimal patient care. Clinical leadership roles may be shared among frontline health care providers, regardless of the position held in the organizational hierarchy, to ensure positive patient outcomes. However, shared clinical leadership works best in flatter organizational structures and nonhierarchical patterns of human relationships. Strong hierarchical organizational structures and ways of relating may present a challenge to the implementation of shared clinical leadership in clinical settings. Further research to explore the influence of context and organizational structure on conceptualizations of clinical leadership may be required.

\section{Acknowledgments}

Special thanks go to D. Stanley (Professor of Nursing, University of New England, Western New South Wales) for his comments on the draft of this article. This paper is part of a doctoral study partly funded through a scholarship from the College of Health Sciences at the University of KwaZuluNatal. This review used secondary data from several databases available to the public. Except for the data presented in this study, there is no additional data for sharing.

\section{Author contributions}

SM (University of KwaZulu-Natal) was the project leader involved throughout the study processes, from project design to write-up. 
AV (University of KwaZulu-Natal) is the first author's PhD supervisor who made conceptual contributions and provided technical guidance throughout the writing processes (revising the article and approval of the final version for submission).

All authors contributed to data analysis, drafting and revising the paper and agree to be accantable for all aspect of the work.

\section{Disclosure}

The authors report no conflicts of interest in this work.

\section{References}

1. Daly J, Jackson D, Mannix J, Davidson P, Hutchinson M. The importance of clinical leadership in the hospital setting. J Healthc Leadersh. 2014;6:75-83.

2. Doherty J. Improving Public Hospitals through Effective Clinical Leadership, Lessons from South Africa. Johannesburg: 2014. Available from: https://www.wits.ac.za/media/migration/files/cs-38933-fix/migratedpdf/pdfs-5/Clinical leadership report V4.pdf. Accessed May 24, 2017.

3. Wong CA, Cummings GG, Ducharme L. The relationship between nursing leadership and patient outcomes: a systematic review update. J Nurs Manag. 2013;21(5):709-724.

4. National Committee for the Confidential Enquiry into Maternal Deaths. Saving Mothers 2011-2013: Sixth Report on the Confidential Enquiry into Maternal Deaths in South Africa. Pretoria: National Committee for the Confidential Enquiry into Maternal Deaths; 2014.

5. Pattinson R, Rhoda N. Saving Babies 2012-2013: Ninth Report on Perinatal Care in South Africa for the PPIP Group. Pretoria: Tshepesa Press; 2014. Available from: http://www.ppip.co.za/wp-content/uploads/ Saving-Babies-2012-2013.pdf. Accessed May 23, 2017.

6. Pattinson R. Improving emergency obstetric care. Int J Gynecol Obstet. 2010;110(2):87-88.

7. Van den Broek N [webpage on the Internet]. Life Saving Skills Manual: Essential Obstetric and Newborn Care. 2nd ed. Cambridge University Press; 2007. Available from: https://www.amazon.co.uk/Life-SavingSkills-Manual-Essential/dp/1107654742. Accessed May 24, 2017.

8. Doherty JE, Couper ID, Campbell D, Walker J. Transforming rural health systems through clinical academic leadership: lessons from South Africa. Rural Remote Health. 2013;13(2):2618.

9. Mountford J, Webb C. When clinicians lead | McKinsey \& Company. McKinsey Q. 2009;2:44-53.

10. Casey M, McNamara M, Fealy G, Geraghty R. Nurses' and midwives' clinical leadership development needs: a mixed methods study. $J A d v$ Nurs. 2011;67(7):1502-1513.

11. Davidson P, Elliot D, Daly J. Clinical leadership in contemporary clinical practice: implications for nursing in Australia. J Nurs Manag. 2006;14(3):180-187.

12. Patrick A, Laschinger HK, Wong C, Finegan J. Developing and testing a new measure of staff nurse clinical leadership: the clinical leadership survey. J Nurs Manag. 2011;19(4):449-460.

13. Curtis EA, de Vries J, Sheerin FK. Developing leadership in nursing: exploring core factors. Br J Nurs. 2011;20(5):306-309.

14. McNamara MS, Fealy GM, Casey M, et al. Boundary matters: clinical leadership and the distinctive disciplinary contribution of nursing to multidisciplinary care. J Clin Nurs. 2011;20(23-24):3502-3512.

15. Pickering C, Grignon J, Steven R, Guitart D, Byrne J. Publishing not perishing: how research students transition from novice to knowledgeable using systematic quantitative literature reviews. Stud Higher Educ. 2015;40(10):1756-1769.
16. Vandenbroucke J, von Elm E, Altman DG, et al. Strengthening the Reporting of Observational Studies in Epidemiology (STROBE): explanation and elaboration. Ann Intern Med. 2007;147(8):W163-W194.

17. Tong A, Sainsbury P, Craig J. Consolidated criteria for reporting qualitative research (COREQ): a 32-item checklist for interviews and focus groups. Int J Qual Health Care. 2007;19(6):349-357.

18. Pluye P, Hong QN [webpage on the Internet]. Appraising qualitative, quantitative, and mixed methods studies included in mixed studies reviews: the MMAT. Annu Rev Public Health. 2011. Available from: http://mixedmethodsappraisaltoolpublic.pbworks.com. Accessed June 8, 2017.

19. Ennis G, Happell B, Reid-Searl K. Enabling professional development in mental health nursing: the role of clinical leadership. $J$ Psychiatr Ment Health Nurs. 2015;22(8):616-622.

20. Mendis D, Paton C. Perceptions of clinical leadership amongst West Midlands registrars. Int J Leadersh Public Serv. 2014;10(2):108-122.

21. Burns D. Clinical leadership for general practice nurses, part 1: perceived needs. Pract Nurs. 2009;20(9):466-469.

22. Trimmer W. The Way Things Are Done Around Here: Perceptions of Clinical Leadership in Mental Health Nursing. 2007. Available from: http://repository.digitalnz.org/system/uploads/record/attachment/195/ the_way_things_are_done_around_here_perceptions_of_clinical_leadership_in_mental_health_nursing.pdf. Accessed May 24, 2017.

23. Stanley D, Cuthbertson J, Latimer K. Perceptions of clinical leadership in the St John Ambulance Service in WA. Response. 2013;39(1):31-37.

24. Stanley D, Blanchard D, Hohol A, Hutton M, McDonald A. Health professionals' perceptions of clinical leadership. A pilot study. Cogent Med. 2017;4(1)1321193.

25. British Medical Association. Doctors' Perspectives on Clinical Leadership. London: 2012. Available from: https://www.bma.org. uk/connecting-doctors/search?q=Doctors $\% \mathrm{E} 2 \% 80 \% 99 \% 20$ perspectives\%20on\%20clinical\%20leadership. Accessed August 4, 2016.

26. Jonas S, McCay L, Keogh B. The importance of clinical leadership. In: Swanwick T, McKimm J, editors. ABC of Clinical Leadership. 1st ed. Oxford: Blackwell Publishing Ltd; 2011:1-3. Available from: https:// scele.ui.ac.id/berkas_kolaborasi/konten/MKK_2014genap/ABC.pdf. Accessed May 22, 2017.

27. Doherty J. Strengthening Clinical Leadership in Hospitals: A Review of the International and South African Literature. Johannesburg: Municipal Service Project; 2013. Available from: https://www.wits.ac.za/media/ migration/files/cs-38933-fix/migrated-pdf/pdfs-5/Strengthening clinical leadership in hospitalsVers2.pdf. Accessed May 23, 2017.

28. National Health Services Institute for Innovation and Improvement. Shared leadership underpinning of the MLCF. Enhancing Engagement in Medical Leadership. Coventry: 2009. Available from: http://www. leadershipacademy.nhs.uk/wp-content/uploads/2012/10/776bc9c27b6 e8741d0ff42e593ba44cf.pdf. Accessed May 24, 2017.

29. Lunenburg FC. Power and leadership: an influence process. Int J Manag Bus Admin. 2012;15(1). Available from: https://pdfs.semanticscholar. org/7965/8afc91bc9b8a8966f3827e372e3656c7bfce.pdf. Accessed May 24, 2017.

30. Al-Sawai A. Leadership of healthcare professionals: where do we stand? Oman Med J. 2013;28(4):285-287.

31. Giltinane L. Leadership styles and theories. Nurs Stand. 2013;27(41): $35-39$.

32. Hagbaghery M, IMahvash S, Fazlolah A. The factors facilitating and inhibiting effective clinical decision-making in nursing: a qualitative study. BMC Nurs. 2004;3(1):2.

33. Patton $C$ [webpage on the Internet]. Conflict in health care: a literature review. Int J Healthc Admin. 2014;9(1). Available from: http://ispub. com/IJHCA/9/1/20081. Accessed May 24, 2017.

34. Fairholm MR. Different perspectives on the practice of leadership. Public Adm Rev. 2015;64(5):577-590.

35. Slide C. The five intelligences of leadership. Leader Leader. 2007; 43:19-26. 
Journal of Healthcare Leadership

\section{Publish your work in this journal}

The Journal of Healthcare Leadership is an international, peer-reviewed, open access journal focusing on leadership for the health profession. The journal is committed to the rapid publication of research focusing on but not limited to

Healthcare policy and law; Theoretical and practical aspects of healthcare delivery; Interactions between healthcare and society and evidence-based practices;

Interdisciplinary decision-making; Philosophical and ethical issues; Hazard management; Research and opinion for health leadership; Leadership assessment. The manuscript management system is completely online and includes a very quick and fair peer-review system. Visit http://www.dovepress.com/ testimonials.php to read real quotes from published authors.

Submit your manuscript here: http://www.dovepress.com/journal-of-healthcare-leadership-journal 